\title{
Library instruction: \\ Recreating the image
}

\author{
By Barbara Love \\ Reference Librarian \\ St. Lawrence College
}

\section{A report on the 16th Annual Workshop on Instruction in Library Use.}

$\mathbf{T}$ he imaginatively titled theme of the 16th Annual Workshop on Instruction in Library Use, "Recreating the Image," prepared the ground for an extremely stimulating conference. The workshop was held May 13-15, 1987, in Hamilton, Ontario, on the leafy grounds of McMaster University (where 100th birthday celebrations were underway) and was jointly sponsored by McMaster and Mohawk College. The sessions succeeded in shaking some of our beliefs in the value of what we teach and encouraged participants to reconsider both the methods and the content of traditional library instruction.

The workshop opened with an animated debate entitled, "Immodest Proposals: Alternative Futures for Bibliographic Instruction," in which the speakers, Tom Eadie of the University of Waterloo, Tanis Fink from Seneca College, and Jocelyn Foster, a Ph.D. student at the University of British Columbia, considered the intrinsic worth of traditional methods of library instruction and possible alternatives to what we are currently teaching.

Tom Eadie opened the debate with the provocative argument that library instruction, especially when not point-of-use, should probably be abandoned. Repetitive reference questions (on catalogue use and periodical index interpretation) continue unabated even when a well-maintained instruction program is in place. His feeling was that the level of sophistication and information on tours is too great for the student masses herded through the library each fall and that good signage, self-paced teaching workbooks and self-guided audio tours would be of more benefit to students than workshops that take place before the students are motivated by an immediate need. Eadie argued that the generic workshops aimed at teaching students how to do term papers or research assignments have the same design flaw as the one-size fits-all clothing - that of really fitting no one well. On the other hand, the specialized sessions tailored to the needs of a specific assignment, usually turn out to be nothing more than hour-long oral bibliographies.

Tanis Fink countered with a proposal for replacing personalized instruction with computerassisted instructional packages. She argued that CAI is economical and quick and that it will overcome librarian burnout by answering repetitive questions and freeing the librarian to handle the more complex and interesting ones. To bolster her arguments, she cited studies that proved CAI more effective than class instruction and at least as effective as personal tutorials.

Jocelyn Foster aimed to bring the discussion back to earth by advocating, less provocatively, that we continue to do what we are now doing but better and more frequently. She disagreed that 
CAI was a realistic alternative, arguing that the skills we wish to propagate-reasoning, evaluating, and discriminating - can only be taught by people. She added that the more access people have to information, the more they will require facilitators to that information. Finally, she encouraged us to advocate the need for better research tools but added that, until they come along, library instruction compensates for poor tools. The debate left workshop participants wanting to explore different avenues for communicating library research skills. The remaining sessions went at least part way toward dealing with Tom Eadie's objections to traditional instruction and to address Jocelyn Foster's exhortations that we improve upon what we are now doing.

Michael Orme, of the Ontario Institute for Studies in Education, presented a highly entertaining, but ultimately practical, session called "The Effective Use of Humor in Instruction." His thesis was that good pacing and reinforcement techniques enhanced with a healthy dose of humor will keep students interested and motivated. He argued that since people require variation, they will find it for themselves (doodling, daydreaming, chatting, etc.) if it is not provided by the teacher. A stimulus variation strategy builds in novelty, complexity and surprise. By using these teaching techniques, the instructor will be able to get the active attention of the students and will then be able to steer them into learning. Orme stressed that while humor has energizing properties that actually aid the learning process, it has to be subject-related or the teacher will lose credibility. Leavening a class presentation with humor enlivens the class and encourages respect and response. This is exactly the way in which Michael Orme conducted his sessions, a fast and funny hour and a half. It was only after consulting my jokeless notes, that I became aware of how much valuable information was actually communicated. Just as he advised us, Orme exploited the expectations of his audience to upset our preconceived ideas of what he was going to say, allowing us to learn.

Marion Wilburn, coordinator of the Library Techniques Program at Sherdan College spoke on "Structuring a Classroom Presentation." Her three-part message emphasized "simplifying, doing and pacing." Before preparing a classroom session, she advised us to pare down what has to be communicated to an essential minimum, outlining what students must know, should know and could know. She then proposed dumping everything that they could know, most of what they should know, and even (heretically) some of what they must know. After simplifying what to teach, Wilburn advised us to make use of what she described as the "doing" principle: students learn skills by practicing them, so lecturing should be interspersed with workbooks, exercises, manuals, labs, experiments or guides. Finally, for a well-timed presentation, activity levels should be varied at about 20 -minute intervals to keep the students' attention spans at their peak.

Threasa Wesley, coordinator of instructional services at Northern Kentucky University, offered the perfect response to Tom Eadie's opening objections to traditional library instruction. Her session dealt with the instruction program in place at Northern Kentucky which emphasizes evaluative research skills and eschews the teaching of catalogue use and periodical index interpretation. She described the evolution of this process as having begun with a collective daydream about the ideal library instruction session. The "daydreamers" concluded that, ideally, library instruction would teach concepts rather than tools and would stress evaluative research skills. This sort of instruction would bring the library more in line with mainstream goals of higher education-creating intellectual explorers. The evaluative research skills they aimed to teach were: breaking up a complex idea into its component parts, determining appropriate types of primary and secondary sources, raising questions, suspending judgement until research is ended, and questioning the authority of sources. To encourage students to break up a complex idea into components, Wesley described the process of brainstorming on a particular student's topic. The class would be asked to think of that topic from a number of differing viewpoints, i.e. for a science assignment they would be encouraged to suggest sociological, anthropological and psychological aspects of that topic which would ultimately yield more insightful research. To understand and appreciate the differences between primary and secondary sources, the students would be asked to read a couple of articles before the class and then to discuss the differing points of view, who holds them, who the authors are, and what background facts the students need to know more about the issue.

Getting students to use library guides effectively was accomplished by making them think about the information from the organizer's point of view. Graduate students might role play and take the parts of a writer, and editor, publisher, acquisition librarian and indexer in order to understand why and how certain types of information are published, bought by libraries, classified and indexed. To demonstrate timeliness, the librarians take a subject heading like "communism" and show students how differently titles from Reader's Guide have appeared over the last four decades. A class in marketing research might be given a brief oral bibliography and discussion about the organization of the sources. The librarian then uses a case study to get the class to develop a marketing strategy that makes use of the various sources.

To get the class to discriminate among the suggested information sources, they may be asked to compare audience level and point of view from citations on the same topic from Reader's Guide and the Social Science Index. This may be followed up 
with a comparison of actual articles. In addition, the same sort of comparison could be done with a photocopy of a subject microfiche card to estimate the likely information yield based on titles, dates, numbers of pages, etc.

This session was a literal eye-opener to the majority of us who have previously questioned how but not $w$ hat to teach in a one-hour library instruc- tion class. The idea that the session can be made far more interesting to both the librarian and to the students and ultimately more valuable in terms of advancing educational goals, seemed truly revolutionary. No doubt, many of the workshop participants have returned to their jobs with a clear-eyed goal and a great deal of insight into recreating the image.

\section{LOEX Conference moves to Ohio}

The annual LOEX bibliographic instruction conference has been held in Ypsilanti, Michigan, ever since 1971. In 1987 it left home and headed south to Columbus, where the Ohio State University Libraries co-hosted the 15 th in the series on May 6-8. The current plan is to keep the conference on the road for the next several years.

LOEX, the national Library OrientationInstruction Exchange Clearinghouse, was established in 1972 at Eastern Michigan University. Its mission is to promote communication among libraries with instruction programs, to assist libraries interested in developing such programs, to aid in research endeavors, and to coordinate activities among state and regional library instruction clearinghouses. LOEX fulfills its mission in part by providing a clearinghouse of instructional materials and by sponsoring an annual conference.

The Ohio State Program Committee recommended that the general theme of the conference be "Defining and Applying Teaching Strategies." The committee sought a balance between high tech and "low tech" with presentations to be made by BI librarians new to the field and sage advice given by veteran BI presenters.

Several major speakers were featured: Keith Cottam, director of the University of Wyoming Libraries, gave the keynote address, "Teaching: No Greater Professional Role"; Joan Ormondroyd, reference and instruction librarian at Cornell University, addressed the topic of in-service training for BI librarians; Thomas McNally, head of circu-

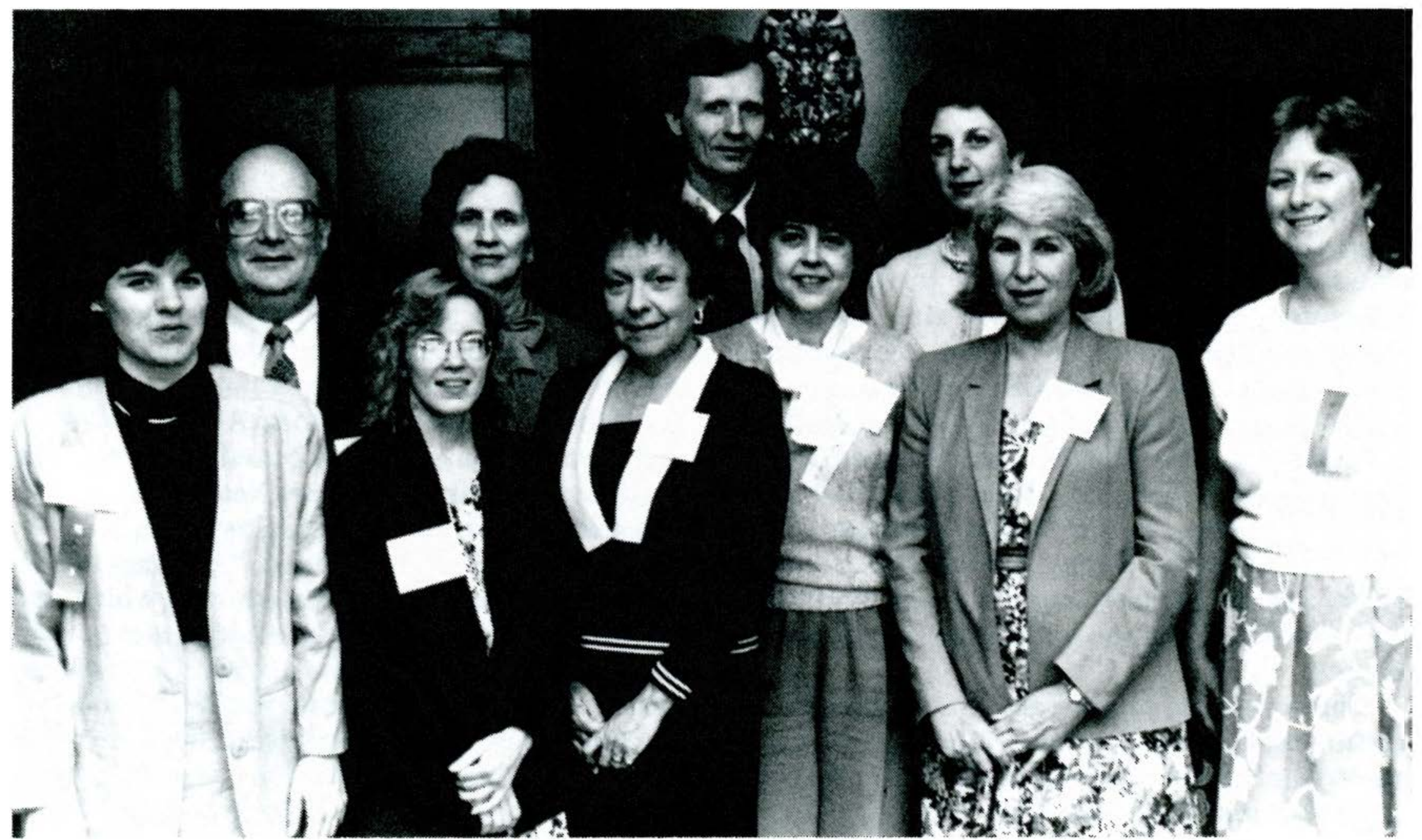

LOEX Conference planners and speakers: (left to right) Mary-Beth Bunge, LOEX program chair, OSU; Jay Ladd, local arrangements, OSU; Teresa Bungard, LOEX director, Eastern Michigan; Virginia Tiefel, user education, OSU; Carolyn Kirkendall, former LOEX director, Eastern Michigan; Keith Cottam, U. Wyoming; Mignon Adams, Philadelphia College of Pharmacy \& Science; Sally Sims, local arrangements, U. Maryland; Joan Ormondroyd, Cornell; and Carol Mularski, volunteer coordinator, OSU. 
lation at Ohio State, provided an after-dinner presentation on the use of video in BI; Mignon Adams, director of library services at the Philadelphia College of Pharmacy and Science, spoke on evaluation; and Mary P. Key, head of the Agriculture Library, Victoria Welborn, head of the Biological Sciences Library, and David Johnson, Department of Natural Resources, all at Ohio State, gave a panel presentation on librarian-classroom faculty team teaching practices.

The program also included 15 presenters selected from a pool of 50 librarians who responded to a call for abstracts. These 15 librarians gave "how-to" talks on topics ranging from activelearning methods to interactive video.

In addition, participants were treated to a lunchtime address by Ohio State provost Myles Brand. Brand not only provided an overview of Ohio State's comprehensive BI program, but emphasized the incorporation of BI into the university's plans for a new undergraduate curriculum.

A highlight of the conference was an evening at the OCLC headquarters in Dublin, Ohio. OCLC hosted a reception and dinner, preceded by tours of the facility. The McNally talk followed in the
OCLC auditorium. Other supporters of the conference included Baker \& Taylor, the Faxon Company, and University Microfilms International.

The 170 conference participants came from 35 states and Canada. More than half of the participants were newcomers to the annual LOEX conference. Most end-of-conference evaluations indicated that the theme was particularly attractive to those starting new BI programs.

The intensive two-day conference was filled to capacity more than a month before the registration deadline, and regrettably, many prospective registrants had to be turned away. The proceedings of the conference, however, will be published by Pierian Press in 1988.

The 1988 LOEX conference theme will focus on the BI needs of special groups, such as returning students, disabled students, and international students. That conference will be held at Bowling Green State University, Bowling Green, Ohio, in early May. For more information on the 1988 conference or about the LOEX Clearinghouse, contact Teresa Bungard, Director, LOEX Clearinghouse, Eastern Michigan University, Ypsilanti, MI 48197; (313) 487-0168.

\section{University of Washington launches traveling exhibit}

The University of Washington Libraries, Seattle, hosted a special reception on May 20, 1987, to celebrate the completion of the Congressional Papers Project and the opening of a traveling exhibit based on the papers of Senator Warren G. Magnuson and the late Senator Henry M. Jackson. Nearly two hundred guests came to honor these two remarkable Senators whose papers reflect an impressive four-decade legacy to public service. Among those present were Senator and Mrs. Magnuson, Helen Jackson, widow of the late Senator Scoop Jackson, and members of their families.

The brief program featured University President William B. Gerberding, Professor Kenneth Pyle of the university's Henry M. Jackson School of International Studies, Robert Burke, professor of history, and Brewster Denny, professor of public affairs. Helen Jackson and Warren Magnuson completed the program with remarks and reminiscences.

This reception, most of all, was a tribute to the distinguished careers of two statesmen who represented the State of $W$ ashington during the tenure of eight different Presidents from the Great Depression to the 1980s. The papers of these two Senators together comprise over 3,000 linear feet of shelving and include correspondence, speeches, writings, notes, reports, committee files, trip files, photographs, audio tapes, $16 \mathrm{~mm}$ films, and videotapes.

Senator and Mrs. Magnuson transferred the Magnuson papers to the University of Washington in 1981. Helen Jackson donated the papers of her late husband in 1983 shortly after his death. Although initial processing had begun when these papers where first donated, a special appropriation by the Washington State Legislature in 1984 allowed a more thorough and expeditious completion of this major project. The computerized inventory of these archives has been reproduced in microfiche and is available from the University Libraries for a fee. Most of the papers are open for use to interested researchers and the general public. Some will be opened at a later date in accordance with the wishes of the donors. As installments of these archives have been processed, they have been made available for public use. Nearly one hundred researchers have already consulted these files.

The 24-panel exhibit entitled, "A Legacy of Public Service," highlights the issues with which each senator was closely associated: commerce, consumer affairs, agriculture, scientific research, health care, environmental policy, defense and foreign policy, and human rights. The early lives and political campaigns of each senator are also featured. The exhibit was designed by Eric Taylor of Taylor'd Exhibits in Seattle in close collaboration with the staff of the Congressional Papers Project and faculty advisers. Throughout this fall, the exhibit will be available to organizations and institutions through Exhibit Touring Services in Olympia, Washington. 


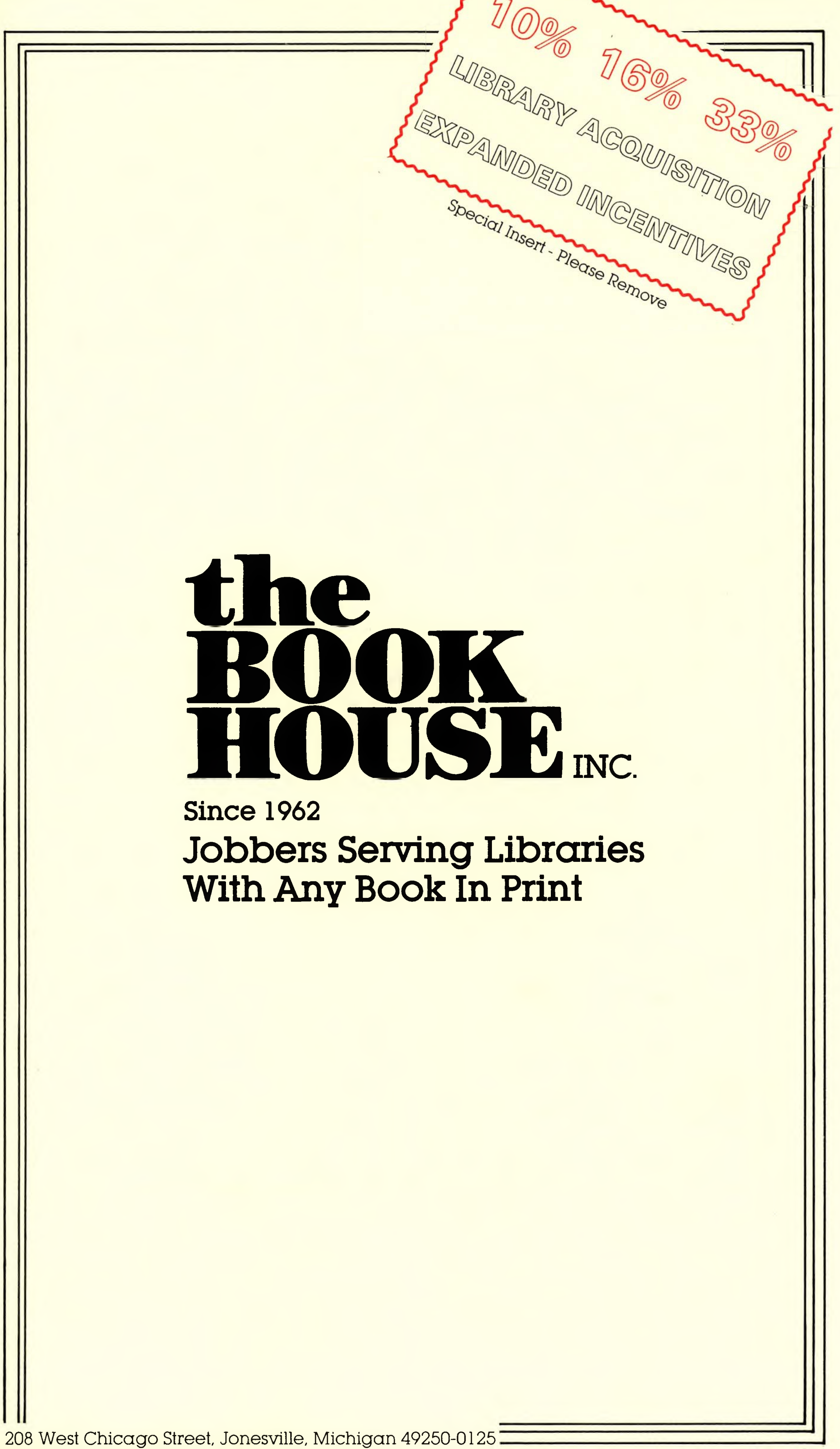

208 West Chicago Street, Jonesville, Michigan 49250-0125 


\section{You are inVITEd to take adVANTAGe of OUR INCENTIVE PROGRAM COVERING THE MAJORITY OF YOUR SCIENTIFIC, TECHNICAL, BUSINESS AND TRADE ORDERS.}

\section{'16\% DISCOUNT \\ Academic Press \\ Ann Arbor Science Pub. \\ Brunner/Mazel \\ Butterworth Pub. \\ Consultants Bureau \\ Elsevier Science Pub. \\ Focal Press \\ Grune \& Stratton \\ Gulf Publishing Co. \\ Halsted Press \\ Harwood Academic \\ Interscience Pub. \\ North Holland \\ Plenum \\ Raven Press \\ Ronald Press \\ Scientific \& Technical \\ Book Service \\ Springer-Verlag \\ V.C.H. Pub. \\ John Wiley \& Sons}

Gordon \& Breach

\section{'10\% DISCOUNT}

Addison Wesley

Allen \& Unwin

Allyn \& Bacon

Amacom Book Div.

American Chemical Soc

Appleton-Century-Crofts

Arco Pub.

Artech

Ballinger Pub. Co.

Birkhauser Boston

Brookings Institution
Chapman \& Hall

Crane, Russak

Benjamin Cummings

Lawrence Erlbaum

Guilford Pub.

D.C. Heath \& Co.

Human Sciences Press

ISI Press

Jossey-Bass (Inc.)

Lexington Books

Linnet Press

Longman
McGraw-Hill Book Co.t Methuen

Pergamon Press

Prentice-Hall Intl.t

Reston Pub. Co.

Routledge \& Kegan Paul Sage Pub.

St. Martin's Presst

Shoe String Press

Taylor \& Francis

Van Nostrand Reinhold

Wadsworth Pub. Co

discount schedule. See back cover. 


\section{$33 \%$ DISCOUNT on trade cloth editions}

Harry N. Abrams Bobbs-Merrill Co. George Braziller Crown Pub.

Dial Press

Doubleday \& Co.

E.P. Dutton

Harcourt Brace Jovanovich Harper \& Row, Pub Henry Holt
Houghton Mifflin Co. Alfred A. Knopf

Little, Brown

Macmillan Pub.

McGraw-Hill Book Co.

Wm. Morrow

W.W. Norton

Pantheon Books

Putnam Pub. Group

Rand McNally
Random House

St. Martin's Press

Scribner Book Co.

Simon \& Schuster

Stackpole Books

Stein \& Day Pub.

Sterling Pub. Co.

Viking Press

Watson-Guptill Pub.

Franklin Watts

\section{$\mathrm{B}_{\mathrm{E}}$ SURE TO INCLUDE ALL YOUR ORDERS FOR THE PUBLISHERS LISTED AND RECEIVE THE MAXIMUM BENEFIT FOR YOUR LIBRARY!}

Our primary objective is promṕt delivery of ANY BOOK IN PRINT from publishers and distributors in the United States and Canada. We remain dedicated to our belief that True Value lies in order Fulfillment and that TIMELY, ACCURATE DELIVERY as well as Discounts are important considerations when determining a vendor's VALUE.

* ANY BOOK IN PRINT From All Publishers in North America

* Complete Order Fulfillment

* Reporting On Backordered Titles

* Invoicing To Your Exact Requirements

* Binding Of Paperbacks

* Rush Orders

* Continuations \& Standing Orders

CONTACT US TODAY:

$1-800-248-1146$

In Michigan and Canada, call collect:

517-849-2117

208 West Chicago Street, Jonesville, Michigan 49250-0125 


\section{DISCOUNTS AND TERMS OF SALE}

Trade

$0-33 \%$

Sci/Tech

$0-10 \%$

Sci/Tech Incentive Program

$5-16 \%$

University Presses

Text

All Paperbacks

$0-20 \%$

Net

Net

Our cost of acquiring non-print material and the publications of most associations, institutes, museums, university departments, authors, etc. exceeds the publisher's list price. In such instances, a service charge of $\$ 3.00$ to $\$ 5.00$ is added to our cost.

Paperback Binding Charges: \$3.29 per book. Please allow 30 additional days for delivery.

Rush Orders: Receive top priority from the moment your order is received. These orders are billed daily and shipped U.P.S. Rush orders are invoiced at no discount and are delivered earlier than regular orders.

Standing Orders: Billed at no discount.

Delivery: F.O.B. Jonesville, Michigan

Handling \& Delivery: $3 \%$ of the net invoice amount is added to cover the costs of obtaining ANY BOOK IN PRINT, frequent claiming, required prepayments, insurance, shipping and guaranteed delivery.

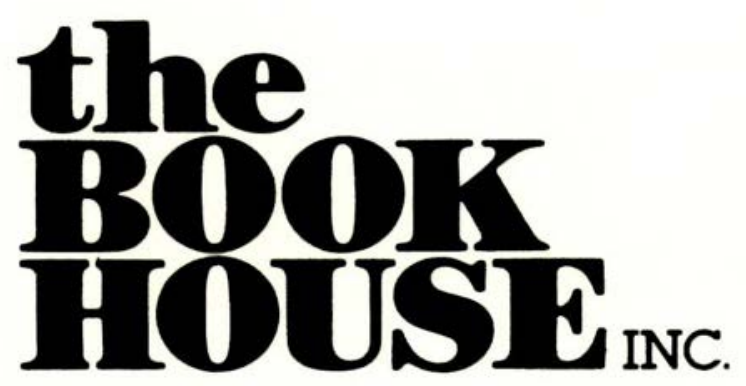

Since 1962

208 West Chicago Street,

Jonesville, Michigan 49250-0125 


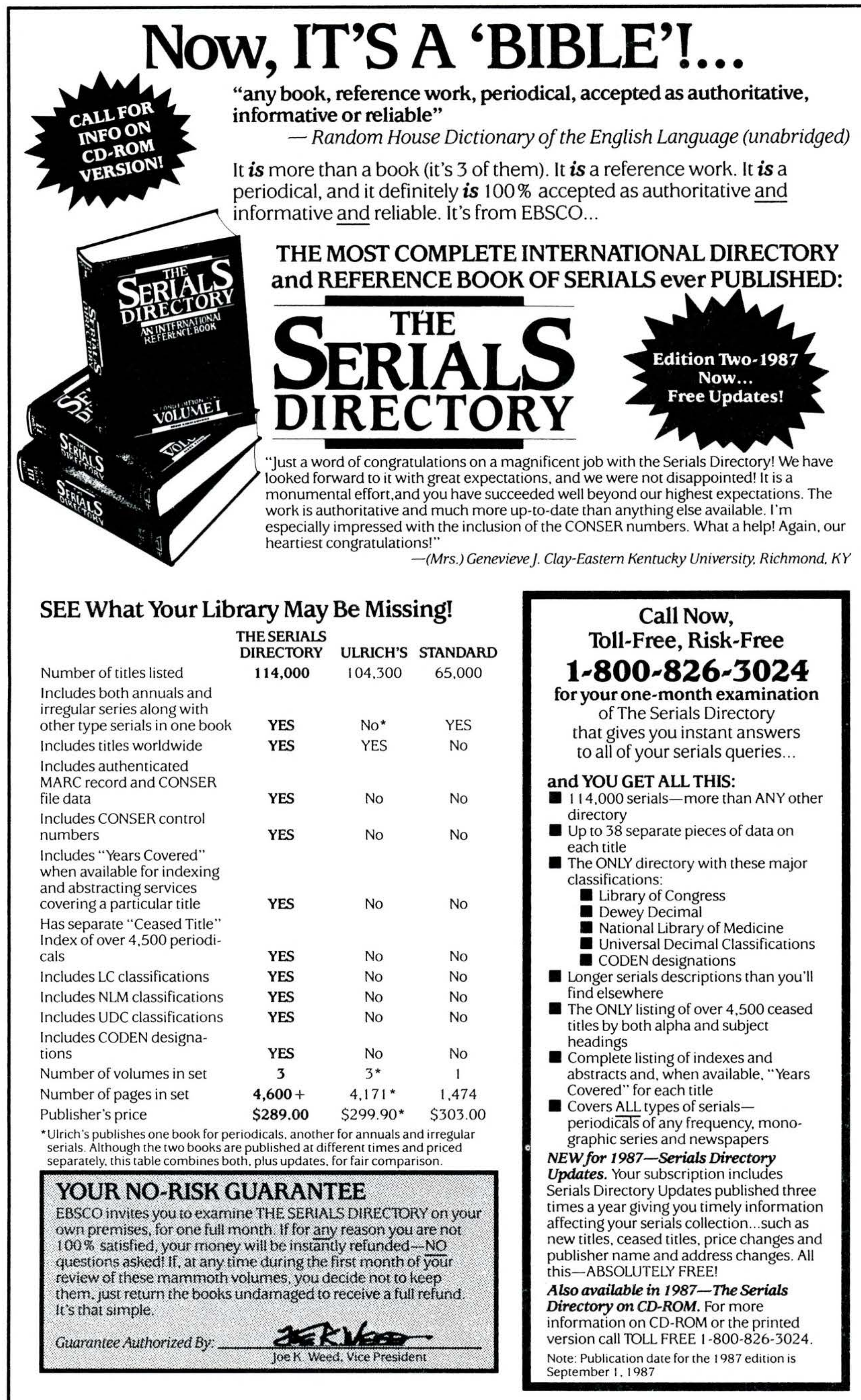

EBSCO PUBLISHING

THE SERIALS DIRECTORY is published by EBSCO Publishing. Box 1943, Birmingham. AL 35201 